\title{
Justicia, Derecho y Arte (Ensayos sobre filosofía jurídica)
}

\author{
José León Barandiarán $\left({ }^{* \star}\right)$
}

\section{$\stackrel{I}{\text { LA JUSTICIA ( }}\left(^{*}\right)$}

G S CON LA MAYOR complacencia que ahora ocupo esta tribuna C para sustentar mi conferencia, después de haber sido presentado con las bondadosas palabras de nuestro digno Decano, doctor Lizardo Alzamora Silva; conferencia que se realiza en ejecución del respectivo ciclo preparado por él, que ha venido a demostrar, una vez más. su celoso interés por todo lo que se refiere al progreso de nuestra Facultad.

(•) L. "La Justicia", fue sustentada en un ciclo de Canferencias đe 1943, siendo publicade en ta Revista de la f acultad de Derecho y Ciencias Politicas. UNMSM, 1943. Aso VII. No. VII. pp, 504 a 511 . Asimismo, por 1 I ditorial Refieves Ameticanos, Lima, 1944.

En csta sección se ha recopilado los cusayos más skenificativos del Maestro, en cuasto a filosofia juriclica. A saber:

II. E.I Movimiento Juridico Europeo

III. H Derscho come categetia dimensional hamana.

IV, 11 Berecho $y$ el Aite.

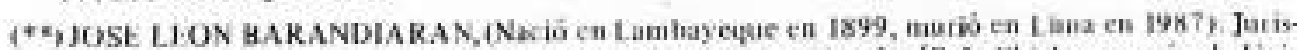
ta y Patricio det Derectur, I yresado del Colecio Nacional "San José", de Chiclayo, pasé a la tini. versidad Nacional Mayot de San Marcos. Fue incoporado a La decencia en la I acultad de Dere. cho $(1928)$, en la cual optó los grados de Bachiller (1925i y de Doctor (1930), asi como el título de Aboeado. Desde entoncer, colaboro activamente en la docencia universitstia al sec nombrado Catedrátixo Adjunto del Dr. Giestavo Cornejo en la Cáredra de Derecho (wil (Oblgacionesh. Asimismo peso de manifísto ses ilustres conocimientos dictando materias bales coma Derecho Constitucional. Derecho Internacional Privado, Dereche Comercial y I ilosofia del De recho. Di tá desde entonces conferencias en diversos medios universistarios y docentes. 
Expreso mi sentido reconocimiento al señor Rector de la Universidad, doctor Pedro Oliveira, por su presencia en esta actuación, y también a mis companeros de labor docente que han concurrido, asi como a todas las personas que se han dignado asistir a esta conferencia, que versará sobre el tema enunciado, la justicia: tema capital en lo que se refiere a las disciplinas juridicas, pues el derecho tiene por causa final y formal la justicia, que es como su entelequia. El derecho viene a ser, asi. el precipitado histórico de la justicia: de modo que la conformación jurídica está predibujada por la idea de la justicia, siendo el derecho a la misma como el acto a la potencia. usando expresiones aristotélicas; de manera que por esa razón el derecho asume un sentido teleológico, pues en todo derecho yace una mónada de valor. No obstante. Ia coincidencia no es absoluta, y derecho y justicia son como dos circunsferencias heterocéntricas cuyas áreas coinciden en gran parte, pero no en forma completa.

La justicia excede al derecho en cierto nodo, y también éste supera a la primera en cierta medida. Esto se comprueba porque a diario nos referimos a apreciaciones que calificamos de justas o injustas y que importan, mas que todo, un sentir, un intuir, que apunta a una consideración moral antes que a una subsunción lógica de carácter estrictamente legal. Tales apreciaciones no tienen una indole juridica, sino, más bien, son estimaciones acerca de meras vivencias o simples hechos causales, Cuando sabemos del caso de un honbre rico que obtiene una loteria, decimos que cllo es injusto. En este supuesto nos referimos a un sentir, más que a una formulación jurfdica. Hacemos mención. en muchos casos. del hombre

I ue, ademifs, profevei em la I'nnersidad Catótica des Peni, San Luis Gonragx de Ica, Pedro Raiz fiallo de Lambayeque, San Markin de Porres $y$ de la tniversidad de I ima,

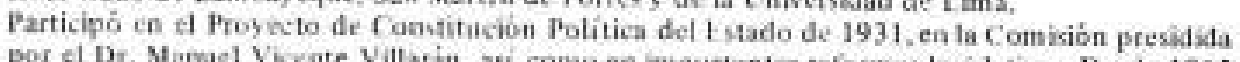
por el Dr. Mamael Vicente Villarin, asi como en inportantes tefornas legislativas. Desde 1965 tratajó concisaudameate en el proveso de Refoma del Código Civia de I936 para luego

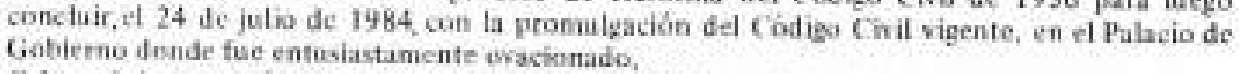

Cabe scalalar tambićn que el lifusine maesto fae Ministro de Justicia y Culto (1948). Decano del Cohezio te Abogados de Lima (1954 55): Decano de la Facultad de Dereclio (1956-57) y Reviar de la thiver dad de San Mareos $(1957$ - 615: Presidente de la Aseciación Nacional de

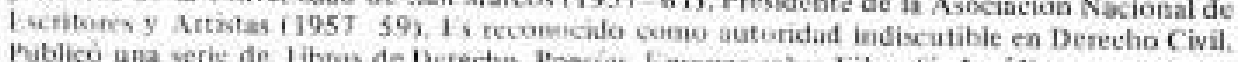
Mublico una seris de Libus de Derectus, Joevias, Ensayos vobse F ilosofía Juridica, evocaciones de costumbres y perseitajes del pasdo. Mencicinase las siguientes obnas princigales: Estredios de

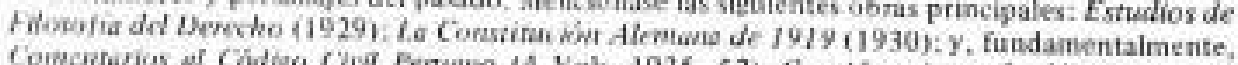

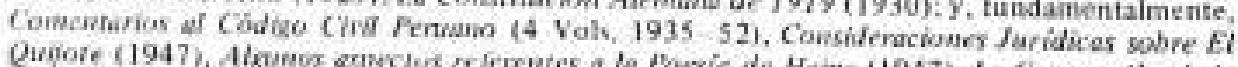

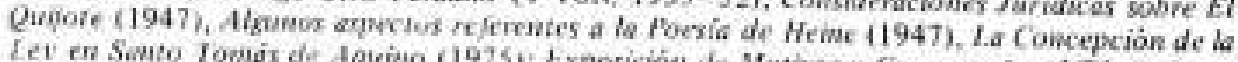

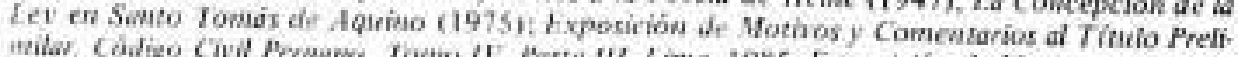

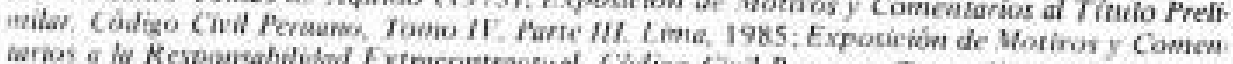

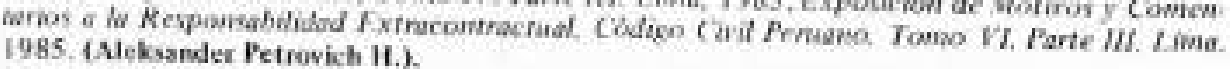


justo para indicar el hombre moral o virtuoso. Asi se habló de Aristides el Justo, de quién decia Plutarco que no sólo contra la benevolencia y el agrado, sino contra la ira y la enemistad era bastante poderoso para mantenerse justo. En este caso se trata de una estimación general sobre la conducta de un hombre; se trata de una referencia vinculada a la equidad y a la moral, más que a un comportamiento estrictamente juridico.

Consideramos ciertos hechos causales cuando hablamos de la suerte injusta y hasta nos atrevemos a hacer la calificación de un Dios injusto, y aún podría anotarse como en la conocida canción mejicana se habla del tiempo "justiciero", "justiciero y vengador". Nos referimos, de otro lado, constantemente, a una justicia divinat que como atributo superhumano aparece con virtualidad trascendente, distinta de la justicia mirada desde un punto de vista rigurosamente juridico.

Las referencias a la justicia como un atributo de Dios, las encontramos en la significación conferida a Brahma, y también en el mito osiriano, en to que representa lsis y en una serie de citas de la Biblia. En ésta se habla también del varón justo para indicar el hombre virtuoso, de justos y pecadores, de hambre y sed de justicia, de Dios que ha de venir a juzgar a los vivos y a los muertos. En el Exodo se lee: "no matarás al inocente y justo, porque yo no justificaré al impio". En Grecia encontramos a Themis, divinidad que encarnando la justicia, es la consejera de Zeus; y se puede también tracr el recuerdo de la fundación del Areópago instituido por Minerva, con ocasión del crimen de Orestes en Clitemnestra, la persecución de las Euménides y la intervención de Apolo.

La justicia aparece, asi, como de un origen divino. En general Dios se nos presente como el Juzgador por antonomasia, el Juez Supremo. En el "Ackermann und der Tod" de Johanes von Zass se dice al respecto: "el Juez de la Justicia soy yo $y$ asi quedo por la eternidad". Apelamos a una justicia divina, que supera a la humana, a una justicia del Cielo, infalible e inviolable. Como se lee en Schiller, cuando el hombre constata que se frustra la justicia de la tierra, alza los ojos con confiado valor hacia el Cielo, donde mora la verdadera justicia, eterna como las estrellas.

Se ve, pues. que hay referencias a la justicia que exceden el marco estricto de lo que comprende el derecho. Pero también, de otra parte, el derecho excede a la justicia. Aquél representa otras finalidades, otros 
valores, además del de la justicia. Si el fin es el ereador del derecho según la indicación de Jhering. ese fin es pluratista en cuanto comporta el aseguramiento de todas las condiciones de existencia de la Sociedad.

No todo precepto de un Código, de una ley, tiene por exclusivo objeto determinar la justicia. Encontramos una serie de preceptos que podrian llamarse auxiliares, técnicos, definitorios. Así, el artículo que precisa que se entiende por accesorio, el que enumera cuáles bienes son muebles y cuáles inmuebles, el que senala el grado de parentesco. Existen. pues, una serie de numerales que no se refieren a una formulación sobre la justicia.

En los preceptos legales yace inmersa una significación estimativa. En muchos, en la mayoría sin duda, encontramos que el valor que contienen es típicamente el de la justicia. Asi, cuando se ordena que nadie debe enriquecerse sin causa, cuando se impone reparación por daño causado. cuando se fulmina el uso abusivo del derecho. Pero si se examina otros preceptos, se descubre que ellos consagran otros valores, como el representado por la seguridad, un orden jeraraquico y de autoridad, el mantenimiento de una situación, el principio de solidaridad y cooperación. la paz social.

Fl valor representado por la seguridad se encuentra, verbi-gratia, en el precepto que establece la exigibilidad de la promesa abstracta o, por ejemplo, en la determinación reglamentaria de que el tráfico se haga conservando la derecha y no la izquierda, o en la fuerza que se le concede a la cosa juzgada. Hallamos tambien preceptos que consagran el principio de autoridad o de orden jerárquico, como en los que perteneeen a la institución de la patria potestad, de la manus, en la sujeción del curatelado y del tutelado frente al curador o tutor, o en el derecho de primogenitura. Un valor es el dado por el mantenimiento de una situación ya constituida: asi la regla del Código Civil de que el bien subrogado, en lo que concierne al régimen de bienes en el matrimonio, se repute de la misma categorfa del otro bien materia de la subrogación; la disposición de que al poseedor se le tenga como propietario: la restricción en cuanto a los efectos rescisorios en los contratos. Hallamos también valores que encarnan el principio de cooperación y solidaridad. Tal el mandato de que la usucapión cn favor de un condómino favorece a los otros, el régimen de servidumbres prediales, el principio de la divisibilidad en las obligaciones. Se puede también encontrar otros valores en el derecho, como el de la paz, social; por tso se explica que el contrato tenga fuerza de ley entre las partes; por eso se admite el arbitraje y la transacción: por eso cada condómino pucde 
ejercer los derechos inherentes a la propiedad, pero siempre que sean compatibles con el estado de indivisión de la cosa.

Hay, en consecuencia, valores que no se refieren únicamente a la justicia, como los enumerados anteriormente. Pero la justicia es el valor fundamental y, en cierto modo, los demás le están mediatizados.

Para entender lo que importa la justicia, conviene examinar los elementos integrantes de todo precepto legal. Cossio encuentra tres elementos. El primero es el consistente en su estructura egológica. Aquí formulamos un juicio noseologico, que imprime un carácter formal y apriori al precepto. Se trata de vincular conceptos, mediante una cópula imputativa entre una premisa y una consecuencia lógicamente conectadas. Este juicio tiene que ser lógico. Estamos en el campo de la apreciación epistemológica, de la apreciación del objeto, pero sólo en cuanto conceptualmente es considerado. Por ejemplo, cuando el Código relaciona daño y reparación. El segundo elemento es el objetal, o $5 \mathrm{ca}$, que versa sobre la estructura ontológica del precepto; ys no considera a los objetos como predicaciones de nuestro conocimiento, sino el objeto en sí en cuanto a su existencia misma como dato entitativo. es decir. que se trata de una apriciación en cuanto al contenido objetal, a lo que constiuye el precepto cono ser real. Asi, en el caso del precepto que establece la responsabilidad por el dano causado con culpa, se evamina las notas ónticas de lo que es daño, responsabilidad, culpa. El tercer clemento es el axiológico y consiste en uno de los valores que comprende la estimativa juridica, putes todo precepto consagra un valor; es decir, contiene ese elemento axiológico referente a un ser ideal: el valor; de tal modo que este clemento es distinto del ontológico, que respecta a un ser real.

Tenemos, pues, los tres datos antes indicados $y$. consecuentemente. hay tres actitudes para aprehender dichos elementos. En lo que concierne al dato lógico, mejor dicho, noseológico, hay el procedimiento de análisis $y$ sintesis que permite distinguir $y$ vincular la premisa a la consecuencia en la relación formal respectiva. Como actitud concordante con el segundo elemento, el ontológico, tenemos la que Cossio llama la adecuación objetal, que permite explicar el contenido entitativo del precepto. En fin, y como actitud que corresponde al tercer elemento, tenemos la dada por una vivencia estimatoria, que posibilita descubrir el valor que reside en la norm". 
Hay también tres métodos correlativos. En lo que se refiere al primer elemento, el método propio es el racional deductivo; en cuanto al segundo elemento, el método adecuado es el inductivo, y con respecto al tercer elemento, el método intuitivo esencial. Mediante tales métodos y actitudes aplicados a los elementos antes mencionados, se tiene lo que se llama lógica juridica, ontología juridica y axiología juridica.

Pues bien, la justicia se estudia dentro de la axiología jurídica, porque ella es un valor; pero, como lo manifestamos antes, hay tambiẻn otros valores en el derecho.

Mas, surge la pregunta: ¿quẻ es la justicia? Sabemos que es el valor primario y fundamental en el derecho. Pero ahora se enfrenta el observador a la dificultad de precisar lo que ella es. La fórmula "dar a cada uno lo suyo" ha sido reprochada de imprecisa. Creemos que ella no debe ser entendida como una de contenido empírico y fáctico, sino como un principio regulativo y no constitutivo, para usar expresión kantiana. Kant dijo: "obra de manera que la máxima de tus acciones puede elevarse a principio de legislación universal"; concibiendo asi una regulación en el campo de la moral, de validez apodietica, como un apriori con su generalidad y universalidad, $\sin$ referencia a un empirie material y concreta. Pues bien, en Derecho una fórmula correlativa es la que se expresa con "dara cada uno lo suyo". como principio ideal, normación general y universal en su validez formal. como una de consideración adráfora, sin que sea menester practicar una enumeración casuistica y empírica de los datos contingentes que integran concretamente la justicia.

La justicia, por lo demás, puede entenderse en diferentes sentidos; pero existen dos cardinales. El primero, como administración dirimente de sifuaciones judiciales y el segundo en un sentido más profundo, en un. sentido deontológico, como criterio ideal, paradigma del derecho. En el primer caso se trata del ejercicio, de la praxis del derecho, como cuando digo administración de justicia, tribunales de justicia, funcionario de la justicia. Stammier nos hace notar esto, cuando recuerda que en los Salmos de David se ensena que "el Derecho ha de mantenerse como tal y ganará todos los corazones". Podemos observar cómo mediante una expresión hipostatica. se nombra o se nombraba "El Justicia" en Espanta para desig- 
nar a quien aplica el derecho, $y$ lo mismo ha ocurrido en Inglaterra con la expresion the justice.

En otro sentudo damos a la justicía una significaciỏn superior, mucho más trascendente, ajena al juzgamiento mismo. Así, se lec en El Quijote: "La justicia se estaba en sus propios términos, sin que la osasen turbar ni ofender los del favor y los del interés, que tanto ahora la menoscaban, turban y persiguen. La ley del encaje aûn no se habia sentado en el entendimiento del jucz, porque entonces no habia que juzgar ni quien fuese juzgado". Aquí la justicia aparece en su más alta y auténtica significaciỏn. como aquello a que aspira realizar el derecho, como la idea que predibuja a éste, como una realidad trascendente e hiperfenoménica frente a los resultados concretos que en el derecho vigente se plasman.

En su acepeión general, la justicia nos hace pensar en una armonía, proporcionalidad, equivalencia, adecuación. Asi la entendió Pitágoras. dentro de su filosofia numérica. como una relación de compensaciones y equivalencias. Hoy se entiende la justicia con un criterio más profundo, como una relación inter-subjetiva de acuerdo a cierto tipo $y$ en base a cjerto criterio. Ella asi resulta vinculada al hombre. En si misma es trascendente, es decir, es un valor que no ha creado el hombre. Existe como un valor per se; pero es un valor que se transforma en inmanente para, en consecuencia, ser realizado por los hombres en el sentido de que a estos compete descubrir y consagrar la justicia. En el Talmud se lee: "Dios es justo: por eso el hombre debe ser justo". La justicia está, pues. vinculada a la vida del hombre, y asi la entendió Platón, considerándola como una curitmia espiritual, en el sentido de una virtud individual y social a la vez: esto es, la virtud entera, así como la injusticia viene a importar el vicio entero; toda vez que la justicia viene a constituir una relación adecuada entre las demás virtudes y se erige, así, en principio supremo de armonía y perfección.

Aristóteles hizo el análisis minucioso del concepto, con el método característico de este filósofo, examinándolo en su carácter eminentemente social, que regula las relaciones inter-humanas para el mejor cumplimiento del destino del hombre dentro de la polis.

La justicia ha llegado, de este modo, a asumir un carácter de alteridad, en el sentido de normar las relaciones entre los individuos, para que cada uno obtenga to suyo, to que propiamente le corresponde. En la epistolu de San Pablo a los Romanos se lee: "Pagad a todos lo que debéis; al que tributo, tributo; al que pecho, pecho; al que honra, honra". Esto 
significa reconocer que se debe dar a cada uno lo que le corresponde por derecho, lo suyo. Del Vecchio nos recuerda la recomendación de Confucio: "Que el principe sea príncipe, que el subbdito sea subbdito, que el padre sea padre, que el hijo sea hijo", y la indicación de Simmel cuando encuentra que lo interesante en este apotegma está en atribuir a cada persona su posición que le corresponde por naturaleza y la determinación consecuente de los deberes que se le asignen.

La explicación de la justicia como una virtud de carácter social se fundainenta, a la vez, histórica y dialècticamente. Lo primero, porque el hombre siempre ha anhelado la justicia y la ha encontrado como una relación de tal indole, social. Lo stzundo. porque no se puede concebir la justicia en otra forma si no es integrándola dentro del conocimiento colectivo humano. No se concibe, a lo menos con los mismos caracteres, con respecto a los ciclopes, por ejemplo. que llevarian una existencia autarquica, o concernientemente a los animales. La justicia esta referida al hombre como un denominador de las cosas, según dice Lapradelle. Con clla se aspira al bienestar general común. a base de un principio regulador de armonía. Por eso es un valor que se vincula a otros valores. Lo justo siempre asocia lo bello y lo bueno, asi como lo injusto suscita la impresión o la idea de lo desagradable y lo malo.

Desde luego, como se comprende, la justicia importa un dato constante de renovación y progreso para el derecho positivo. Ella representa un ideal nunca definitivamente logrado: el derecho viene a ser como una linea asintética que no llega a alcanzar absolutamente a la excelsa justicia. Aquí es donde se puede hablar de una "lucha por el derecho", según la expresión de Thering: aqui es donde nos hallamos frente a un trabajo perpetuo. a una faena incesante, por mejorar, por perfeccionar el derecho, asumién. dose una actitud no estática ni conformista, sino dinámica y progresista. renovadora, idealista en el mejor sentido de la palabra.

En todo caso, nunca podemos concebir que no debe reinar la justicia entre los hombres. Con una crítica retrospectiva podemos encontrar instituciones juridicas injustas; pero a larga vista, perspectivando el problema digamos protensivamente, hallamos que siempre se proclama la definitiva victoria de la justicia. En Isaias se lee: "oidme los que conocéis 
la justicia ... no temais afrenta de hombre ni desmayéis por sus denuesdos ... mas. mi justicia permanecerá perpetuamente".

Se puede distinguir una justicia abstracta de una concreta. Fn algún caso concreto puede faltarse a ella, en el sentido de que se produzca una decisión que sea injusta. El jucz puede equivocarse. Pero la ley no debe equivocarse. Hay aquí una distinción fecunda entre el mundo del ser y del deber ser, en la que ahora nos podemos detener.

Sin la justicia, abstractamente considerada. la vida no mereceria la pena de ser vivida. Se cuenta una anéculota sobre Alejandro Magno, quien quiso presenciar cómo un rey del Asia Menor administraba justicia. El caso que le tocó presenciar era el siguiente: en un terreno un individuo que no era su propietario, descubre un tesoro y ambos, el dueno del terreno y el descubridor, disputan sobre el derecho al tesoro. El rey cavila. Después preguntia a uno si tiene un hijo en edad de contraer matrimonio, y cuando responde que sí, pregunta al otro litigante si tiene una hija casadera, recibiendo respuesta afirmativa. Entonces da su veredicto, diciendo que el joven se case con la muchacha, si se quieren, y el tesoro les pertenezca como dote para el matrimonio que otorgan los padres. Como el rey nota el asombro de Alcjandro, le pregunta si se hubiese fallado el caso en otra fonaa en su pais. Alejandro le responde que se habría resuelto que el tesuro perteneciera al Monarca, Pues entonces. replicó el rey, no merecuría que en tu pais ulumbrase el sol, ni cayese la lluvia, ni fructificase el suelo. porque no se habría heclso justicia.

Un caso irritante de injusticia puede, por lo mismo, perturbar toda la existencia de un individuo. como en el caso de Michael Kollhas, y puede agitar toda la vida politica de un pueblo, como en el caso Dreyfus.

Se ha constatado la posibilidad de una oposición entre la legislación y la justicia, y para vencer la oposición se recurre al principio de la equidad. como un medio de mitigar lo abstracto y riguroso de la ley. Esta como regla general. no apunta al caso concreto, y la equidad es comparada a la regla lesbia que permite adecuar al caso singular la solución mís justa. dejando entonces de ser ley el lecho de Procusto. Pero la equidad puede conducir at consecuencias inconvenientes, si se hace de ella un uso exagerado, arbitrario. Laprichoso. Entonces, como dice Mayer. asi como la ley 
aplicada sin ponderación es comparable a un Pegaso uncido, la equidad sin freno es como un corcel desbocado.

La equidad puede degenerar en el entregarse a la decisión simplista y profana, a buen entender y leal saber, y puede acarrear la inseguridad juridica. Calígula amenazó a los romanos con no aplicar la ley sino la equidad; alguna vez se dijo: "Dios nos libre de la equidad del parlamento". y los ciudadanos de Saboya rogaron a Francisco I que no los gobernase por la equidad.

La colisión entre la ley y la justicia ha dado origen a que en los casos de decisiones injustas se apele, como una protesta y como un constielo, a la justicia del Cielo. oponiéndola a la falibilidad del criterio humano. Efectivamente, encontramos en el hecho que se dictan leyes injustas. Irónicamente ha escrito Anatole France que la ley en su majestuosa igualdad prohibe tanto a ricos como a pobres mendigar en las calles, dormir bajo los puentes y robar el pan. Se comprende que la ley humana puede ser injusta; pero siempre, como una suprema liberación, se cree en la inviolable justicia que reside en el Cielo. Al respecto encontramos el mito de Astrea. a que hace referencia por ejemplo Shakespeare en su Tito Andrónico: de Astrea, quien abandona la tierra cuando por primera vez, se perpetra una injusticia. para refugiarse en el Ciclo y defender así su pureza inmaculada.

De otro lado, se descubre como anota Del Vecchio, que se comete abusos, excesos intemperancias. a nombre de la justicia. A veces las revoluciones incurren en excesos deplorables, cohonestándolos en nombre de ella. Se puede hablar aqui de un fanatismo de la justicia, como en el caso concerniente a Robespierre; y en la literatura encontramos el tipo fanático en administrar justicia en la figura de Dandin, en Les.Plaideurs de Racine. en cuanto se obstina en condenar a galeras al perro Citron por haber robado un pedazo de carne.

En gencral, digamos que la justicia viene a significar un criterio de imparcialidad, mesura, ponderación y desinterés. Es como un obrar con inteligencia, pero sin que se exceda en pasión, que trabaja sine ira et sine 
studio. Esto explica los simbolos con que se representa a la justicia; la balanza, la venda, la espada, la virginidad, que son los que mejor interpretan esa imparcialidad que es nota insita en la justicia. No se puede concebir a ésta aliada a un interés particular, porque ella es lo opuesto al egoísmo. De alli la máxima de que nadie es juez en causa propia; que el juez. debe escuchar a ambas partes; que todo lugar es, salvo a quién vive en justicia, como indicaba Epicteto; que parcialidad es sinónimo de injusticia: que a nadie se le debe negar justicia ni a nadie aplazársela, como reza la Magna Carta: "sé justo y no temas nada", se lee en el Enrique VIII de Shakespeare.

Digamos ahora, antes de concluir, que el deber de todo individuo es acatar la ley y la sentencia judicial. En general ellas son justas. $Y$ tal acatamiento se debe por un principio de seguridad, Recuérdese el ejemplo de Sócrates que nos da en el Criton, cuando el filósofo dice a sus discipulos que no podía desobedecer la ley y la sentencia, pues él ha enseñado que el respeto por ellas es base esencial para la existencia de la ciudad. De otro lado, encontramos la indicación que aparece en la novela de von Kleist, "Michael Kollhass", con el protagonista quien habiendo sido victima de una injusticia se pone al margen de la vida legal, hasta que finalmente se persuade de que su proceder es incorrecto y muere arrepentido.

Si la justicia es una virtud, un valor, todos los hombres debemos trabajar por ella, esforzándonos para que encuentre su consagración en la forma más perfecta posible. Hay una inextinguible "sed y hambre de justicia". No importa que no la pueda definir con exactitud ni precisarla en su contenido especifico. Flla existe, se descubre, se intuye.

El juez por su propia función profesional, tiene el deber de excelente responsabilidad, de discernirla en el caso concreto sujeto a su determinación. Pero es también deber de todos, un deber humano general, el que tenemos de trabajar en toda ocasión por la justicia, o sea, que hay que cortar, como dec ia Jhering, la cabeza de hidra de la injusticia alli donde ella se levante. No importa que no sea un jurista. Zolá no lo era y luchó por una causa de justicia con un fervor de apostolado con su célebre j'accuse. Y es que vivir es tener una responsabilidad; es decir, estar frente a una tarea por cumplir. la propia y digna del hombre, que es propender a realizar valores como el de la justicia, la verdad, la bondad, la santidad y la billeza. 
La vida no es, pues, una cosa constituida, sino algo que a diario se hace y se construye. Somos, por lo mismo, participes en la actividad del Cosmos porque podemos realizar valores. Frente a la angustia de la muerte. que a todo hombre acecha, frente a la constatación de la fugacidad de nuestro paso por el mundo, nos podemos consolar, sabiendo que somos algo y que hacemos algo; y así el hombre satisfará a su conciencia y podrá mostrarse digno del don de Djos al darnos la vida. Hay muchas determinaciones o actos sin mayor importancia, en los cuales podemos decidirnos en uno u otro sentido. Es la esfera subestimable de nuestra actividad vital. Pero hay otros actos que exigen una preferencia, una toma de posición fundamental, para elegir entre lo iusto o injusto. Es la esfera importante, trascendental. en nuestra actividad vital. Es aqui donde debemos adherirnos siempre a las soluciones que sean justas.

El hombre de derecho tiene la obligación especifica de trabajar por la justicia, por razón de disciplina, por educación, por hábito; èl debe, pues, con redoblado empeno, esforzarse para que triunfe la justicia en su mejor forma posible.

Asi podemos sentirnos contentos con nosotros mismos en cuanto cooperamos para ennoblecer y dignificar la vida.

Con esto concluye esta conferencia. Yo habia pensado desarrollar otro: puntos que conciernen al tema; pero he comprendido que he querido ser demasiado codicioso: pues si la justicia por definición es lo contrario al abuso, yo creo que debia comenzar por ser justo $y$, asi no abusar más de vuestra santa paciencia.

\section{II EL MOVIMIENTO JURIDICO EUROPEO (*)}

En el siglo XIX hubo una detención en el desarrollo de la Filosofía por motivo del predominio en la mente humana de una actitud positivista. concentraindose la atención en los hechos, su observación experimental y su explicación causal. La ciencia arrumbaba despectivamente a la Filosofia tratándola como una especulación inútil: $y$ diriasc que se habia alcanzado

(*) Este ensayo se pubticó en la Revisza dd Foro, Lima, 1953, Año XV, No. 3, Setiembre - Diciem bre:PP, 421 430. (A.P.H.Y. 
aquella última etapa que Compte señalaba en la evolución de la inteligencia humana.

Dentro de la inordinación que el Derecho, entendido desde el punto de vista de la Filosofia, ha tenido respecto a esta ültima, se puede percibir una dirección en el pensamiento jurídico concorde con la nueva orientación campeadora en el siglo próximo pasado. Los estudios de Filosofía del Derecho se abandonan en Europa, las cátedras de esa disciplina desaparecen. La investigación juridica se cine dentro de los contornos sociológicos o, a lo sumo, se hace ciencia general del Derecho, pero en el sentido más estrecho de la expresión. Se bus a para el Derecho una explicación historicista, o de fisonomía utilitaria o pragmatista $y$, de todos modos. teñida de positivismo. La circunstancia de que el Derecho se refiere a hechos sensiblemente aprehensibles, cuales son los manifestados en el comportaniento efectivo de los hombres en una determinada esfera de su actividad, podia cohonestar esa posición que, de otro lado, resultaba en cierta manera explicable como una evasión y un alivio frente al prolongado y excesivo esfucrzo de la reflexión europea en las especulaciones filosóficas, con tal magnitud y de tanta intensidad como las emprendidas por el idealismo alemán. que culminase con el sistema densísino de Kant y el mayestático de Hegel.

Desde fines del siglo XIX hay una reacción frente a esa tendencia positivista, y el "retornemos a Kant" es un slogan que revela una necesidad de la mente europea para volver a sus preocupaciones por la filosofia. En el deseo de regresar hacia la misma se encontraba el renovado esfuerzo en presencia de los dos grandes sistemas antes citados que habian sido tan prolijamente estructurados, y usi se explica que surgieran dos consecuentes movimientos, el neokantismo y el neohegelianismo. Hubo. pues, una vuelta a Hegel, asi como una vuelta a Kant. Las dos posiciones antes mencionadas tuvieron su natural repercusión en el campo del derecho. Los grandes sistemas filosóficos de la edad moderna se ocuparon del derecho, tratando a éste como un capitulo dentro de aquéllos. Así ocurrió con Kant, así con Hegel, $y$ antes con Leibniz. En el derecho, en cuanto éste concierne a la conducta humana, se vio siempre como tenía que scr, un asunto que instaba a la reflexión filosofica. Con la aparición del neokantismo y del neohegelianismo, surge otra postitura en lo que al derecho en relación a los mismos concierne. A diferencia de lo que ocurrió en cuanto a los predichos sistemas, podriamos decir clasicos, va a suceder en el siglo XX que el planteamiento de los problemas del derecho desde un punto de vista filosófico se hace por juristas, aunque inspirándose en los sistemas de filosofia a que tales juristas resultan afiliados. 
La posición varia, pues, notoriamente. No es el caso de filósofos que trabajan con el derecho. por cuanto a virtud de ta plenitud orgánica de sus concepciones el último ha de quedar comprendido en ellas, sino es el caso de juristas que especificamente se dedican at indagaciones juridicas, aunque en base a una formación prefigurante dada por determinada dirección filosófica. La filosofia del derecho resultó así, aunque necesariamente subordinada a la filosofia en general. con una caracterización propia, que le confiere su misma connotación de juridica.

El movimiento neokantiano, por lo demás, tuvo dos manifestaciones derivadas de dos vertientes, que procediendo del pensador de Koenisberg. se han distinguido a virtud de que una se ha modelado en el criticismo de la razón teórica, y la otra ha reconoeido su basamento en el criticismo de la razón práctica. La primera, que vino a constituir la llamada escuela de Marburgo, se ahincó en el análisis gnoseológico, como punto central de la creación kantiana en su Crítica de la razón pura; la segunda, que vino a ser conocida como la escuela del Sudoeste alemán, se encaminó a una apreciación estimativa de los valores, como enlace con lo asentado en la Crítica de la razón practica. Una y otra tuvieron sus exponentes en el ámbito de la filosofia del derecho.

El neokantismo en la dirección primera sirvió de punto de apoyo a Stammbler y a Kelsen con la denominación escuela de Viena.

Fue Rudolf Stammbler una figura cimera de la vida universitaria tudesca. Con él se restableció como asignatura universitaria en Europa la de filosofia del derecho, que había desaparecido bajo el embate del positivismo del siglo XIX, Su libro capital, "EI Tratado", sirvió de texto de consulta muy principal para los cultores de la indicada disciplina; y la influencia del maestro fue considerable por algún tiempo en el viejo y en el nuevo continente.

A semejanza de lo que le ocurrió a su mentor, que se encontró en la encrucijada entre un racionalismo y un sensualismo, y se afanó en superar tal punto crucial al desbrozar un nuevo derrotero, el del criticismo, asi Stammbler en lo ateniente al derecho hubo de hallarse delante de un bravio dilema: de un lado con la tradición de pretencioso abolengo del jus naturae y. de otro lado, con el impacto que contra éste último hiciera Savigny con su relativismo histórico. El mismo podria decirse que sacaría a cualcuier jurisprudente, v.g. a Stammbler, de su "sueño dogmático", como Hume hiciese con Kant. según propia mención. La originalidad stammbleriana consistió en idear la famosa formula de un derecho natural 
de contenido variable. Ella ha hecho o hizo a lo menos fortuna, cuando el stammblerismo estaba en auge. Lo cierto es que cualquiera que haya sido el juicio definitivo que ha venido a merecer esta concepción central del jus filósofo de Halle, se enlazaba con fidelidad con la crítica de la razón pura y su distinción entre materia y forma. La intrusión de apreciaciones sobre la idea de la justicia y de ciertos residuos de metaficismo, pese a la posición gnoscológica de Stammbler, dio lugar a reproches; a lo que hubo de agregarse que, como todo idealismo dualista, se encontró frente al embarazo de la methésis, la distinción y correlación entre lo a priori, en el caso de Stammbler el juicio de validez universal como ratio cognoscendi, como principio general gnoseológico sobre el derecho, y la realidad juridica misma, en cuanto a los procesos fácticos de la voluntad humana. Todo ello, a la par que el interés que concitó la teoria de Kelsen, fue en mengua del ascendiente de la doctrina stammbleriana.

Kelsen ha sido reputado por muchos como uno de los más esclarecidos representantes en los tiempos contemporáneos de la disciplina del derecho. Lo distintivo en él ha sido esa pulcritud metodológica en cuanto a la caracterización normológica propia del derecho. Su teoria, según propia declaración del autor, es una teoría pura del derecho; como teoria comporta un estudio especulativo sobre tal objeto científicamente contemplado, que es el derecho: pero para remarcar la severidad del método, agrega la expresión de pura. De lo que esmeradamente ha cuidado el gran profesor, es de mundificar su elaboración de toda ingerencia de elementos foráneos a la investigación estrictamente jurídica. El ser y el deber ser, los hechos como tales (mundo fáctico, de la naturaleza) y las normas (mundo de la finalidad) exigen dos maneras de concebir distintas. El derecho pertenece al mundo de la finalidad y requiere su propia imputación normativa; tipificándose la norma como un juicio imputativo, de especial relación copulativa entre supuesto y consecuencia. Dentro de la pureza acrisolada metodológica, Kelsen cuidó celosamente en quedarse herméticamente dentro del plano netamente jurídico; por donde cualesquiera otros elementos de consideración de indole moral, sociológica, histórica, metafísica quedaban descartadas como meta o.como extrajurídicos. El estudio del Derecho dentro del derecho podía ser la divisa del jefe de la escuela de Viena: y si así se nos permitiese hablar, osariamos decir que de su teoría podría proclamar, como en el reclamo de ciertos productos: ¡es un artículo no adulterado! Fn cierta manera Kelsen procedió como aquellos exégetas de la hermenéutica francesa del Código Civil, en cuanto ellos se atuvieron exclusivamente a lo que al último pertenecia, dentro de un legalismo llevado a su extremo: y Kelsen trazó en el plano de las meditaciones juridicas un circulo estricto para no triscender de él; pero 
para acabalar todo to relacionado con aquéllas tomadas en sentido de una teoria rigurosamente juridica. No quicre decir to anterior, sin embargo. que Kelsen desconozca la utilidad de análisis de otrat clase referentes al derecho, como por ejemplo los sociologicos, sỏlo que a èstos los transfiere a otro plano. Kelsen, como se sabe, ha escrito un libro de factura sociológica, titulado "Sociedad y Naturaleza".

Es digno de destacar que Kelsen, con humildad cientifica ha admitido algunas rectificaciones en su primitiva concepcion: viendo en la norma, al lado del aspecto lógico, el de un imperativo: de suerte que ha dado cobijo en ella a un ingrediente de orden ontológico. Por eso al presente, la construccion kelseniana distinque entre norma de un lado. en cuanto representa una ereación de derecho como ordenamiento declarado : impuesto por la autoridad legisladora sobre el conducirse humano y, de otro lado, regla juridica, en cuanto mero conociniento y descripción del derecho. He aquí to que expreso en una de sas conferencias en Buenos Aires: "Llamamos reglas del derecho a las proposiciones mediante las cuales la ciencia del Derecho describe su objcto. Es necesario distinguir estas reglas de derecho, de las nomas juridicas que creadas por los actos de las autoridades juridicas, forman el Derecho, objeto de la ciencia del Derecho. Fn mi "General Theory of Law and State" he presentado muy cuidadosamente esta distinción. Pero en mis obras anteriores, quizàs. no he sido suficientemente claro en lo que concierne a esta distinción: y asi he provocido mal entendidos y objeciones, algunas de las cuales me parecen ser justificadas".

El desco de evadirse de una clucubración puramente formalista prescindente de datos, hechos, fenómenos, de la realidad juridica en fin. explica la aparición de dos tendencias que apartandose de la influencia kantiana, arrancan y obedecen a otras inspiraciones; el neohegelianismo y la fenomenologia.

En lo que hace a esta última, ya sea en cuanto a las Investigaciones Lógicas de Husserl, o a sus Ideas, ya sea en cuanto a la teoria de los valores estructurada por Scheller y Hartmann, ya sea en cuanto al descnsolvimiento existencialista presidido por Heidegger. juristas han podido aprowechar de ese acervo filosófico para tratar lo concerniente al derecho.

Es bien conocido que el libro de Schreiber "Conceptos y Form.1s Fundamentales del Derecho", es un ensayo de caracterización de la norma como ente ideal, en cuanto comporta una relación de términos de carácter categorico. vale decir, no contingentes, no adventicios: ta cual 
por lo mismo ha de ser captada por intuición ideatoria; resaltando también cómo ha aprovechado la tan acuciada discriminación husserliana entre expresión. significación y objeto, aplicándola al derecho. La obra de Schapp "La Nucva Ciencia del Derecho", como es conocido, también se alinea en la posición fenomenológica. Antes, sin duda el pionero en el campo virgen de investigaciones fenomenológicas, Reinach, trabajó con su discutido libro "Fundamentos aprioristicos del derecho civil". $\mathrm{Si}$ es verdad que hubo quién como Binder dijera que el que leyese la obrat de Reinach se llevaría involuntariamente las manos a la cabeza en gesto de asombro, Husserl mismo la llegó a elogiar. Imposible detenerse ahora en lo referente a Reinach o en Kautrmann, por ejemplo, en cuanto se ocupan de las llamadas legalidades juridicas puras, como conjunto de juicios sintéticos a priori, o en cuanto tratan de la intuición esencial para captar lo eidético juridico.Gerald Husserl, por su lado, tomó como punto de partida a Heidegger. para considerar que si el hombre es un ente ónticamente ontológico, vale decir con idoneidad propia y radical para estando en el mundo comprenderlo, necesariamente ha de estar sujeto al cometido de abrirse al mundo del derecho, entendiéndolo como un modo de comportarse frente a él. Además, llevó a cabo un análisis del tiempo en relación al derecho, en cuanto éste pretende perdurar, pese a que todo lo que es dado al hombre en el mundc natural es perecedero; por lo cual sóló se puede vencer dicha tensión de angustia mediante la ley, que temporaliza al derecho, por esencia destemporalizado.

El movimiento negohegeliano ha significado, a semejanza del neokantismo, un remontarse hacia el idcalismo alemán, con las consiguientes rectificaciones al dogmatismo de la sistemática acabalada del mentor. Lo ingente del contenido hegeliano, el activismo y las posibilidades de un ágil evolucionismo dialéctico de las formas del pensamiento y de la vida, eran incitantes motivos para que pudieran del copioso árbol surgir retoños gallardos. El neohegelianismo en sus repercusiones juridicas ha florecido en Italia, bajo los nombres de Croce y de Gentile. Para Croce la vida del espiritu en cuanto obrar práctico ( $y$ aqui ha de entenderse que se hace mención del espíritu objetivo) se manifiesta (dialécticamente hablando) en dos momentos: economia y moral, en base a la calidad de fines pretendidos, ya individuales o ya universales, incrustándose el derecho dentro de la primera manifestación de actividad humana; con lo que se disuelve la autonomia de aquél y se llega, por otra via, a anălogo resultado que el marxismo con su distinción de infra estructura (lo económico) y super estructura (lo jurídico) sociales; pero, de otro lado, lo interesante de la conceptuación croceana reside en haber aprovechado lo vivo, lo dinámico, lo práctics del hegelianismo. en cuanto a volición concreta como constitu- 
tiva de ba actividad juridica, precisamente como réplica al formalismo y al abstraccionismo tan peculiares del neokantismo marburgiano.

También de filiación neohcgeliana y menos heterodoxamente que Croce, es Gentile, euya postura st explica precisamente desde un punto de vista dialéctico, como oposición a Croce. al colocar fientile el acento en la etica, hasta el punto que en bucna cuenta la misma viene a absorber lo juridico, haciêndole perder sta autonomía entitativa; y construyendo una abstrusa distinción entre querer querido y querer actual, que en último término sólo puede hacerse con un criterio gnoseológico formalista, con inconsecuencia del propósito inicial de supeditar ese criterio, para alcanzar realidades metafisicas, de acuerdo con la indole del hegelianismo. Binker, por su parte, y Larenz. tambièn. son corifeos dentro de la tendencia neohegeliana en el derecho. En general se extrae la impresión de que tal tendencia no logra solucionar con satisfactoria plenitud los problemas del derecho, pues o cave en la conclusion de reducir al mismo dentro de otras disciplinas o actisidades, como en el caso de los profesores italianos premencionatos, o lleva a conciliaciones a veces dificiles y forradas o que cuando menos no resultan debidamente justificadas.

Ft esfucroo emprendido por la denominada escuela del Sudoeste alemán. en el sentido de proyectarse hacia el examen de los valores en cuanto a fines e ideales en los que viene a operar lo que se conoce como cultura, significando un aporte de indiscutible importancia, ha suscitado diligente interes en el orden jusidico. De inmediato se hace notorio a cualquiera mente la relación que la cultura debe tener con el comportamacnto ético. latu sensu, con la vida humana en cuanto transitada por deberes intersubjetivos $y$, por ende, con el derecho, que es regulacion sino de toda, de parte y muy extensa de esa vida, en cuanto conducta normada por êl mismo. por el derecho.

En dicha posición. que representa un formalismo axiológico (formalismo por su origen kantiano, en cuanto a buscar principios regulativos más que constitutivos, dados por la razón prictica; axiológico en cuanto trata de valores) se destacan los nombres de Lask. Mayer Radbruch y Situer, cuyos méritos sin duta residen en distinguir entre mundo de la naturaleza y mundo de los valores absolutos. para en seguida considerar Lexistencia de un tercer ambito, el de la cultura. dentro del cual resulta insertado el derecho.

Con todo, una apreciación rigurosamente aquistada sobre los valores wolo $\mathrm{x}$ atcanza con la aplicación del mérodo fenomenologico a traves de 
tos trabajos monumentales de Scheller y Hartmann, que permiten situar a la persona humana dentro de una escala axiótica, para comprender así su puesto y su responsabilidad en la vida, y que reconociendo que los valores son esencias irreales, se encaman en el hacer humano, creando una verdadera trasmutación el ser ideal al ser real, mediante una exigencia normativa, un quehacer timético que a la persona humana corresponden.

En Francia, bajo el deslumbramiento hipnotizante que suscitara la gran creación del Código Civil de 1804, los estudios del derecho centraron su enfoque en el comentario de dicho cuerpo legal. y de este modo surgió lo que se ha llamado la escuela de la exégesis. La sumisión fidelísima, el culto fetechista del texto, la hermenéutica ortodoxa, la búsqueda hasta intimista del pensamiento del legislador, la sutileza en la recurrencia al argumento dialéctico, vino a aparejar asi un método sui géneris, que era como una especie de escolaticismo juridico. Y como el trabajo se polarizaba básicamente en la interpretación de un Código como el Civil, resultaba una marcada preferencia por el derecho privado como elemento empleable para las grandes obras de comentarios.

La reacción contra la exégesis se hizo sentir y acaeció en la misma Francia, como una necesidad de desatar a la propia jurisprudencia, entendida ésta como ciencia del derecho o como aplicación pretoriana, de los valladares con los que la cercaba la escuela exegética. Saleilles ya se pronunciaba por no quedarse en el aimbito del Código, y más tarde apreció la prestante figura del Geny. Teniendo cierta afinidad con el pensamiento bergsoniano. el profesor de Nancy propugnó una libre investigación cientifica. pura superar el estatismo de la ley y permitir que ésta pueda transcurrir en una como evolución creadora. de acuerdo a las exigencias variables de la vida misma; y en una cauta posición ensayó conciliar lo dado y lo construido. lo que está predeterminado por irrecusables datos primarios de lo juridico y lo que resulta como técnica manufactura a posteriori por el jurista. Leroy subestima la ley, que como fuente formal del derecho coloca por bajo de la costumbre y la actividad jurisprudencial $y$ aun del ordenamiento estatutario, por cuanto aqui opera un derecho más espontáneo y más dinámico que el necesariamente estatilizado en la ley. Hay quićn lance esta divisa atrevida: jla rebelión de los hechos frente a la ley! Y Charmont ha de aceptar que la desuetudo ejerza una función abrogante del derecho escrito.

Al hilo de todo el anterior movimiento, se ha gestado también en Francia lo que se ha llamado teoría institucionalista. El criterio es supraindividualista y de acuerdo a la tipificación que le ha atribuido Hauriou, 
Renard y Delós, es la institución como una idea volitiva que teleológicamente está enderezada a realizar, en forma más o menos perdurable, un determinado fin social, mediante procedimientos y organización conducentes a tal resultado: derivando de todo ello la propia conformación autárquica del ente institucional. Esta fecunda concepción institucionallista ha sido uno de los más valiosos aportes proporcionados para el análisis de la realidad jur idica.

Legaz Lacambra, con razon ha visto un parentesco entre tal anterior teoria institucionalista y el "pensamiento ordenalista" concreto de Karl Schmidt.

No faltan en el desarrollo del pensamiento juridico contemporáneo las revivencias de un jus naturae, No es, desde luego, el restablecimiento de una entidad metafisica. porque en tal carácter el viejo derecho natural quedó definitivamente cancelado desde la critica de Savigny, que culminase con la de Berghom, Es una mera contemplación del tema que sostayando todo presupuesto metafísico, mira al derecho natural en tanto una exigencial de orden lógico universal, como un postulado deontológico irrecusable, como tn el caso de Del Vecchio, o en tanto recibe su unción justificadora de la eticidad inserta en la idea del derecho, pues el jus naturae segun expresa Coing on su recientisima obra Grudzäge de Recbts. pbilosopbie: "es la suma de los principios arraigados en la moralidad y en la realidad para la conformación del ordenamiento social. El exige al mismo tiempo a la moral obligatoria y al orden positivo el configurar sus correspondientes principios fundamentales". (pág. 168).

El pensamiento juridico curopeo ha encarado todos los problemas que pueden concurrir a una inspección sobre el derecho de acuerdo a las diversas corrientes filosóficas que han prosperado en el siglo XX. No falta tampoco la actitud escéptica, acogida por la llamada escuela de Upsala. que como retomando el reto de Kirchmann hace más de un siglo sobre qué se demostrara que existe una auténtica ciencia juridica, viene a proclamar una especie de níhilismo jurídico, viendo en aquélla sólo como una fantasiosa y por ende caprichosa clocubración cerebral, $\sin$ base ni apoyo reales de ninguna clase.

Verdaderamente, ante tan frondosa y variada proliferación de sistemas y tendencias (no todas aqui siquiera mentadas) coincidentes en determinados puntos unas y discrepantes otras, mostrándose algunas dentro de una fidedigna consecuencia a anteriores concepciones (principalmente al Kantismo) y otras desviándose sensiblemente, y no faltando tampoco 
entre ellas las que resultan dificiles de insumir dentro de un patronazgo definitivo por el eclecticismo que pretenden alcanzar, ante tal situación que concierne al estudio del derecho en la actualidad, tal vez precisa formular dos cuestiones capitales. La primera es si el derecho como ciencia ha de conservar su independencia; la segunda respecta a cuál debe ser en definitiva el planteamiento fundamental que al derecho compete de acuerdo a lo que intrinsecamente es.

La ciencia del derecho como dogmática propia, como un sistema de conocimientos que no queda absorbila hasta perder su autónoma existencia por otras disciplinas, se esfuerzal en defenderse con vigor frente a esa coyuntura. No sólo frente a la filosofía, sino también frente a la sociologia.

La filosofía es siempre absorbente, dominante, prepotente, pese o precisamente por su propia idiosincracia problemática. Como antiguamente la teologia, la filosofía se muestra propensa a ejercer una función hegemónica en agravio de cualquier otra disciplina con la que entre en conexión. Como, de otro lado, el derecho tiene que entendérselas con la conducta humana y esta última se manifiesta necesariamente por datos fácticos de inmediata impleción, hay là proclividad de que el derecho sea mediatizado como mero elemento utilizable de explicación sociológica. Scría erróneo y peligroso reducir el derecho a una simple sociología juridica, refundiendo_uno de los términos de la relación intersistemática en el otro, hasta propiamente hacer desaparecer al primero. Como ha escrito Ruiz del Castillo "el derecho, si fuera condicionado y no condicionante, dejaria de ser normativo. Si ha de regir la vida social, no puede extraerse totalmente de ella. Lo que rige se impone a lo regido o, por lo menos, lo conduce". Y como expresa Castán: "aún cuando llegase a tener la Sociologia del Derecho una precisión de que todavía carece, no podría suplir la misión de la ciencia jurídica ni la de la Filosofia del Derecho. Ciertamente, puede haber un concepto sociológico del Derecho, pero el punto de vista del sociológico no es el que al jurista fundamentalmente interesa. La concepción del Derecho en sentido jurídico (si vale la frase) es esencialmente normativa".

En Europa un pensador de la talla de Karl Schmidt ha remarcado la necesidad de salvaguardar la dogmática juridica y nos ha recordado el ejemplo edificante protagonizado en el siglo pasado por Savigny. al manumitir al derecho de la tradición agobiante del jus naturae, para considerar el método cientifico que al derecho en general legitimamente pertenece. 
El derecho no puede dejar de ser apreciado por la filosof ía en cuanto a la problernatica fundamental que aquél of rece; pero ha de ser tratada por ésta última sin que se olvide que cualquiera reflexión filosófica sólo importa un referente ante un referido, que es el derecho.

Como el pensamiento juridico europeo se revela generalmente concorde en ver en el derecho un conjunto Je normas. Ha cuestión central es la relativa a saber en qué consisten las mismas.

Lo que importa es determinar la estructura formal de la norma, y es Este un problema lógico; y determinar su consistencia óntica-ontológica; y por el propio caracter de lo normativo se tiene que encontrar aqui una estimación axiológica; y el cardinal problema estriba en hallat el vinculo de adecuación entre esa estructura lógica y esa consistencia ónticamente axiológiea.

Los valores estain encarnades en las normas, pues no se dictan preceptos obligatorios para los hombres, para crear significaciones judicativas por un prurito intelectual frisolo o por arbitrariedad. Mas, la norma es categoria generalizadora, y los datos de la condueta se dan en los actos y omisiones prácticos de los casos individuales. Aqui cabe de nuevo hacer una compulsa de valores. Pucidese poner el acento en uno u otro elemento de apreciación. en la norma o en el hecho conereto. y cualquiera de las dos exageraciones es riesqosa por la misma parcialidad que acusa. Es. desde luego, comprobable que frente al exceso en la preferencia normativista que ha predominado en general, se observa en Europa (por lo demás como tambièn en América) una reacción hacia el realismo jurisprudencial: lo que también se ha llamado "jurisprudencia de intereses", "derecho viviente". "decisionismo juridico".

La ley erea el hecho con sentido jurídico, pero fsi se nos permitiese emplear la comparación) como en el caso de Pigmalion de Bernard Shaw. la creatura tiende a revelarse en contra y a dominar al creador, o sea, que et hecho pugna por supeditar a la ley.

Todo el movimicnto anteriormente mencionado responde a una reacción contra la exageración de un normativismo que puede llevar a que descacfea el derecho como fenomeno vital, es decir. presente con mostración inmediata en la vida misma del hombre, para convertirlo en pura entelequia. Ysay ha sostenido la necesidad de ver en el derecho como elemento primariamente determinante, la decision y no la norma: pues lo que importa es resolver el asunto concreto, en un act , creador originario. 
a base más que de una intelección seca y fría sobre una regla abstracta, sobre tuna categoria conceptual huera, ausente de la realidad mundana, en una emoción vivencial que capta intuitivamente la inmediatez del fenómeno dado en el comercio juridico. Ehrlich, por su parte, es el jefe de la llamada escuela de Derecho libre, que recomienda evadirse de las ligaduras legales, para centrar la misión del derecho en la solución estimativa de cada situación a base de un juicio axiológico, zafándose el criterio juzgativo de la malhadada lógica tradicional, engendrada como recurso de artificiosa técnica, para que sirva como efugio que coheneste $y$ oculte la incapacidad efectiva de la ley, que pretende sacrificar lo existencial auténtico de la vida, en beneficio de un mero proceso automático de trabazones silogísticas.

Lo defectuoso en estas tendencias radica en que hacen una transposición tun radical en cuanto a los elementos integrantes del derecho, que puede ir hasta eliminar de este último su virtud de certeza, para dejar librado todo ad natum al parecer del juez, como si se le concediese una letra en blanco, que aquél pueda hacer llenar a discreción.

Lo cierto es que siempre es recomendable recordar el consejo de don Quijote a Sancho: "no te guies por la ley del encaje".

Se alzan, pues, voces para no caer ni en Caribdis ni en Escila. La valorización primaria es la que debe hacerse en base de la ley, como el prius de toda estimación jurídica. La valorización concreta in casu, sin dejar de tener su propia importancia, precisamente por la novedad y variedad de las circunstancias que han de sopesarse, no puede desligarse empero totalmente de la valorización predeterminante dada por la norma, ya que de no ser asi, la última perdería su innato significado y quedaria convertida en declaración meramente literal de un pensamiento, del legislador, vacua, inoperante.

Lo esencial es inquerir por una adecuación entre lo ideal y lo real, entre debe ser y ser, como lo ha intentado Kaufmann, entre normas y hechos como lo preconiza Horvath.

La ciencia juridica tiene frente a sí esa labor. Del pensamiento jurílico europeo actual, después de tantas preocupaciones para mirar el derecho desde diferentes puntos de consideración, deriva el planteamiento sobre un método que vincule realidad y valor, hecho y norma, para una solución integral y plenamente satisfactoria de la caracterización del derecho: $y$ lo que es estimulante para nosotros, hombres de América. 
es que se dan pruebas elocuentes de ensayos y concepciones que paralelamente al movimiento jurídico icuropeo, tambiến propenden al mismo enfocamiento. Ello revela que America va adquiriendo un grado de madurez intelectual, que le permite concurrir en el progreso del saber sobre el derecho. Lo que se anhela, urgentemente, es una concepción integralista del derecho: y el mismo está en inquirimiento por la primera; como en el caso de Pirandello, con el personaje en busca de autor. Todo parecte indicar que se esta en la inminencia de que tenga éxito tal promisora tentativa.

\section{III}

\section{EL DERECHO COMO CATEGORIA DIMENSIONAL HUMANA (*)}

Alguna vez todo hombre ha de preguntarse en concernencia a las ocupaciones y preocupaciones que integran el objeto de su actividad como profesión, oficio. quehacer constante y decisivos en su vida. en qué consiste ese objeto. La pregunta ha de ser siempre inquietante. pues del género de actividad que como tal faenia vital se realice, depende en gran parte la clase de sujeto que se es. Las expresiones idiomaticas que continuamente se emplee isobre todo si se trata de actividades de naturaleza técnica $\mathrm{e}$ intelectuall, cicrtos hábitos sociales, la manera de reaccionar sicológicamente, el estilo de vida en una palabra, está condicionado en un alto grado de coeficiencia por ese dato conformante constituido por lo que el hombre hace dentro del carácter y órbita de lo que se identifica como su metier.

Quien se ocupa y so preocupa del derecho como legislador, como juez, como jurista, como abogado ien la tetralogia fundamental al respecto). es un bomo juridicus. $Y$ esta connotacion de juridico le llega a pertenecer porque siendo en principio en to que hace al hombre, una circunstancia (pues no todo hombre se dedica a los menesteres jurídicos principalmente), en aquét que se dedica a los mismos, tal connotación viene a ser elemento determinante de su modo de comportarse en el mundo.

Mas, resulta dificil a cualquier bomo juridicus dar respuestat it la pregunta que se formule sobre lo que es el Derecho. El mismo es algo que existe, y la comprobación de esa existencia es un hecho que se da de

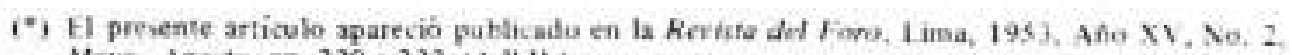
Mayo-Agoots: pp. 320 a 322, A A H. 
inmediato al conocimiento de todo individuo. Pero determinar en qué consiste, es pretender captario como un ser en cuanto tal con la totalidad de sus atributos fundamentales, como un "primo ens". $Y$ esta es una cuestion metafísica. Se tiene. sí, el conocimiento empírico. sensible, de actos aislados de la conducta jurídica, a través de innumerables mostraciones de tales actos que las personas practican. Y se puede tener el conocimiento de la existencia de una determinada regla promulgada por el legislador, mediante una impleción, mediante una verificación intuiti:a. Se aprehende lógicamente la conexión judicativa de los elementos objetales que una regla legal contiene, mediante ya un juicio analitico ad exempium una definición, que a seces se incluye en la ley). ya uno sintético a priori (cuando hay la exigencia racional irrecusable de la vinculación entre el supuesto y la conclusión, por ejemplo que el comprador deba pagar el precio); ya uno sintético a posteriori, pues se ofrecen casos en que una ley en un país o en una época determinada dé una solución distinta a la de otra ley en otro pa is y en otra época (asi. que el estado y la capacidad de las personas se rijan por la ley nacional o por la ley de donicilio, pudiendo ser ambas soluciones legitimas), sin que se atente contra el principio de contradición (toda vez que la incompatibilidad sólo es operante en cuanto se trata de situaciones consideradas en el mismo tiempo y en el mismo sentido), de modo que en la solución influyen circunstancias sociales variables. La norma juridica se comprende, de otro lado, en su sentido axiológico mediante una apreciaciòn estinativa; $y$ desde ese punto de vista en cuanto la regla legal de derecho positivo es una obra humana, ella es un ente cultural.

Hay una verdad irrecusable y ella es que el derecho corresponde al hombre y a su conducta, que cl hombre es el agente causante de las reglas juridicas y el destinatario de las mismas, pues son elaboradas por el hombre, el legislador (en tanto considerado como un ente universal) y para el hombre (el súbdito). El derecho como categoria gnoseológica y ontológicamente hablando, pertenece a la dimensión del existente humano. Toda persona sabe que está sometido a dos círculos dimensionales en su estar en el mundo desde un punto de vista juridico: un límite máximo a su libertad, pues siempre hay un mínimun de prohibido en lo que atane a lo que no puede hacer (limite que esa libertad no puede superar), y un limite mínimo de libertad, pues siempre lo prohibido ha de encontrar un máximun (que por lo mismo no puede superar, en cuanto a to que la persona puede hacer).

Sólo que ocurre que la mente humana es susceptible de presumir que el derecho no sólo rija la vida del hombre, mas también el comporta- 
miento de otros seres, infra-humanos o trans-humanos. Así, cuando considera fantasiosamente las relaciones a que estén sometidos animales o las relaciones de entes metafísicos o imaginarios como Dios, el diablo, la muerte. La literatura nos of rece ilustraciones sugestivas sobre este particular. En "La lliada" y "La Odisea" los dioses aparecen celebrando contratos con los hombres y sometiẻndose a las consecuencias emanantes de aquéllos.

En "Belial Procez", la antigua obra de Petrus Merkel, intervienen Dios, Satán y el Hombre, y todo transcurre dentro de un proceso pulcramente juridico, porque todos los protagonistas han de acatar escrupulosamente las reglas del derecho. Algo semejante se comprueba en "Der Ackermann und der Tod" de Johannes von Zaas, según la versión de Hans Fehr en "Das Recht in der Dichtung" (page 252 y s).

In la Walkiria. el drama musical de Wagner. cuando Wotan quiere cometer un acto arbitrario, ordenando a Brunhilda que ayude al hijo de aquél. Sigmund, en su lucha con Hünding, impide la mujer de Wotan, Fricka, que simboliza la justicia, tal hecho arbitrario, teniendo que doblegarse la voluntad de Wotan. Fs tambien de recordar de que dijera Fausto: " ¿Con qué hasta el mismo infierno tiene leyes?; de este modo un pacto hecho con vos serí fielmente cumplido". Y Mefistófeles: "De lo que se te prometa podrás gozar completamente; nada te será retirado".

En la tradición de Ricardo Palma "Don Dimas de la Tijereta", Satanás ha de atenerse al fallo que se dicta sobre la interpretación de la palabra "almilla", como jubon interior; $y$ pierde ef litigio frente a Dimas.

Fn cuanto a la presentación de animales como titulares de situaciones juridicas, se podria recordar lo atinente al Reinhardt Fuchs de los hermanos Grimm.

Pero es indudable que se trata sólo de una estimacion ticcional para atribuir al derecho un poder de vigencia en cuanto a toda clase de seres que se supasiese pudicran realizar actos juridicos o estar insumidos en situaciones juridicas, Se parte de un punto de vista sofistico, pues aunque las referencias juridicas estin dirigidas a seres infra o extra-humanos. ellas estin apreciadas desde tu punto de vista humano; es el derecho aplicado a tales seres por obra y dentro de la posición conceptual del hombre, incurriéndose asi en un notorio paralogismo. 
La investigación juridica predica necesariamente hacia los datos que integran la cultura humana. E1 jurista no ha de contentarse con conocer su disciplina con un criterio unilateral. Por la incidencia del Derecho en todos los fenómenos de sentido teleológico, le aguarda doble trabajo: ha de estudiar especialmente la jurisprudencia; pero no debe desinteresarse de la cultura en general. No puede tener una mera curiosidad de diletante para todas las manifestaciones de orden ideográfico, sin profundizar su propia ciencia; mas, no puede sacrificar su plenitud humana, enclaustrándose dentro de un intolerante y único quehacer. La visión de la estrella no eliminará la del cielo, ni la del árbol excluirá la del bosque. De aquí que sea interesante considerar las relaciones entre Derecho y Arte.

En la arguitectura y la escultura hay manifestaciones en que está impreso un significado jurídico-político. La arquitectura, como alguien dijera, es el arte más social. Las pirámides de Egipto acusan el carácter teocrático y despótico del régimen faraónico y su altiva inscripción, de que ningún hombre indigena había trabajado en ellas, induce a reflexiones en cuanto a la diferencia legal entre nacionales y extranjeros. En Grecia numerosas obras de estatuaria tuvieron una fisonomía patriótica. $\mathrm{La}$ "Victoria de Samotracia", por ejemplo, que como escribjese Rubén Dario, "hizo hervir a los griegos en las calles de Atenas". Se ha considerado que en la "Athenas Parthenos" de Fidias, encontró su símbolo auténtico dentro del campo del arte, la política de Pericles; en esa obra que, efectivamente, reflejaba toda la-grandeza de esa ciudad en su apogeo. El Fórum y el Agora se alzaban majestuosos, dignos de las funciones que en ellos tenfan lugar, $y$ algo semejante cabe decir de las Basílicas de Roma. En la misma, obeliscos, arcos conmemorativos, columnas históricas, patentizaron un vigoroso sentido social. Toda la arquitectura de la ciudad de los Césares daba la impresión de bienestar colectivo, prepotencia politica, arrogancia imperial, genio guerrero. Y verbi gratia, en Berlín el monumento a Guillermo 1 en la Schloss Platz, y contemporáneamente las construcciones del Congreso Nacional Socialista de Nüremberg; en Washington el Lincoln's Mcmorial; el monumento a Lenin en Moscú, el

(*) Publicado en Reriste de Derecho y Ciencios Folitices. (San Marcos), Lima, 1942, Año VL. No. II. pp, 347 a $362 ; y$ en Editorlal Reliewes Americenos. Lima, 19 t3. (A.P.H.) 
que se alza en la Cordillera de los Andes, en el Cerro de la Gloria, que representa a San Martín y su ejército atravesándola para la campaña libertadora; en Paris el Arco de Triunfo y el Triunfo de la República, la estupenda obra de Jules Dalou en la Plaza de la Nación, ¿quién puede negar que han obedecido a un propósito politico? ¿Y qué indicar de las tumbas al soldado desconocido? Por doquier encontramos monumentos en que se perennizan efemérides patrióticas.

La galeria de bustos del escultor Houdon, de personajes americanos de la gesta emancipadora, atestigua auténtica exaltación admirativa por ese gran acontecimiento.

De otro lado, es de referirse a numerosas esculturas que representan la Justicia. Asi, las de Mino de Fiésole, Bartolomé Prieur. Demesmay. Dumont, Felon, Millet. La admirable obra de d'Angujer, en el Louvre, de una mujer de imponente belleza, con el haz y el hacha, los símbolos de la autoridad consular romana. La alegoría de Andrés Pisano; la estatua de De la Porta, en el monumento a Pablo Farnesio en la Basilica de San Pedro; las de Benedetto de Majano y de Leopardi; la figura de la Justicia que junto a la de la Caridad esculpió Bernin en el Mausoleo a Urbano VIII. queriendo sugerir con ello que la gracia debe templar el rigor de la ley. La de Girouard, de poderosa inspiración, de una mujer de austera hermosura, con la balanza que cuelga de una mano y el brazo derecho en alto blandiendo una espada. La composición de Gilles Lambert Gedecharle, en el castillo de Laecken, sobre "La justicia recompensando a la virtud, protegiendo a los débiles y persiguiendo los vicios". La de John Flaxmann en la tumba a Lord Mansfield, en que aparece al lado de la estatua del mismo. la Minerva y al otro lado la de la Justicia, haciendo comprender que ésta y la sabiduría deben marchar vinculadas. La composición de James Vibert y el grupo Dillens en los Palacios de Justicia de Lausanne y de Bruselles. respectivamente.

Desde otro punto de vista, cabe insistir en la necesidad de que los edificios donde ella se administre, tengan una prestancia apropiada. Seria inconcebible que los mismos fueran de un estilo ramplón o cursi, churrigueresco, recargado, que carecieran de severidad y la sobria imponencia que debe serles propio. Es de elogiar que Lima tenga uno adecuado.

La pintura y el dibujo han sido dóciles en acoger temas que tienen que ver con el Derecho. El "Sansón" del asombrante Rembrandt tiene un 


\section{NUESTROS CLASICOS}

carácter político, y más aún su "Moisés" rompiendo las tablas de la ley Jacques Louis David exaltó el ánimo jacobino en su "Juramento de los Horacios", "Bruto", "La Muerte de Socrates": y lo propio cabe decir respecto a "La libertad de las barricadas", "La batalla de Pothiers". "La paz viniendo a consolar a los hombres", de Delacroix. En "El Dos de Mayo" y los "Fusilamientos de la Moncloa" de Goya están impresos un vibrante entusiasmo patriótico y el horror de la carnicería de la guerra. Haremos referencia a la retractación de Federico Barbarroja a los pies de Alejandro III", de Tiziano; "Carlos V entrando a Paris", de Ingrés.

De otro lado, no puede olvidarse a Daumier, con sus divertidísimas caricaturas sobre el "homo juridicus", y los asuntos de ley, y que también atanieron a cuestiones de politica en general, como su "Libertad de la prensa", "El vientre legislativo", "La Constitución en la mesa de operaciones", Daumier caracterizó al abogado codicioso, al juez indolente y sonoliento, al incauto litigante, victima de la chicanería, el proceso intrincadisimo, rutinario e interminable. "Les gens de justice" es, al respecto, notable. Soglow ha ironizado en ciertos dibujos, a propósito de determinadas disposiciones formalmente en vigor en algunos Estados de la Unión Americana, manifiestamente anacrónicas o absurdas. Keene también se burla en algún dibujo, de los hombres togados. No debería omitirse las caricaturas de indole política. Es el caso de Descamps, especialmente con "Arrềt de la Court Prevolat", y de Forain. Willete tomó en chanza a jucces, autoridades, propietarios, burgueses; todo lo que se califica comúnmente como "respetable".

Otros autores han consignado in el lienzo sus opiniones en materia de Justicia social: Fraonçois Millet, Gustavo Coubert, Constantino Munier. Diego de Rivera; Kollwitz con sus cuadros sobre la guerra de los campesinos. la insurrección de los tejedores silecianos, la Revolución francesa, singularmente "Adelante", de vigorosa emoción social; las escenas de miseria popular debidas al pincel de Van de Venne. Los ensayos del pintor de México, Orozco, hablan de una mística revolucionaria; por ejemplo, "La destrucción del antiguo orden de cosas".

Ferri en "Los delincuentes en el Arte", ha estudiado los tipos criminales en las creaciones de Goya, Proudhon, Boilly, Bernet, Gericault. Ary-Scheffer, Delacroix, Wierta, Rotta.

Numerosas pinturas han simbolizado la justicia, típicamente con la balanza, la espada y a veces con los ojos vendados. Asi, la de Proudhon, en el Lourte, "La justicia y la venganza persiguiendo al crimen". con la 
profunda impresión que despierta. Los frescos de Giotto en la Capilla de la Arena de Padone. "La Justicia" y "La Injusticia". "La Justicia regiamente coronada, sentada sobre un trono de arcaduras góticas, y que sostiene en su mano los dos platillos de la balanza; dos ángeles están de pie: el primero coronando a un obrero en el trabajo, delante de su yunque; el segundo. que decapita a un malhechor postrado. En la base del trono un precioso friso expresa los efectos felices de un buen gobierno". (Michel.Histoire de I' Art.; II. 801). La Injusticia está representada por un hombre de torva faz; a sus pies aparecen los resultados de un mal gobierno. El fresco de Lorenzetti en el Palacio público de Sienne, "El buen gobierno". en que resalta la justicia con su manto rojo. en la mano derecha una corona, en la izquierda una espada, cuya extremidad cae sobre la cabeza de un hombre: por encima dos ángeles que encarnan la justicia distributiva y la conmutativa, y sobre el cielo resplandecen las palabras Diligite justitiam qui judicates ternam, Los cuadros de Pollajoulo y Jacabello. El lienzo de Van der Weyden, "La justicia de Trajano", y el del mismo nombre de Delacroix. El fresco de Tiepolo en la Capilla Calloni y los de Pinturicchio en la Sala de los Borgia en el Vaticano, "La justicia de Trajano" y "El triunfo de la justicia". La celebérrima imagen de Rafael en la Cámara de la Signatura, en que yérguese la justicia sobre las nubes. mirando a los mortales vigilantemente, y con la inscripción Jus saum unicuique tribuens. Alli tambien se exhibe "La jurisprudencia con los legistas". del mismo maestro. El aguafuerte de Dumonsticr; las estampas de Kartaro y Durero; el óleo de Luca Giurdano, "La justicia desarmada por el amor y la ignorancia", en el museo de Nápoles; "La jussticia y la paz" de Rottenhammer; los bocetos de Delville: el cuactro de Metsu. "La justicia protegiendo a la viuda y al huérfano": el de Salvatore Rose. "La justicia se refugia entre los aldeanos". las pinturas de Lehman y Ulmann sobre temas jurídicos; los frescos de Alcalá Galiano en el Palacio de Justicia de Madrid. No olvidaremos los retratos de Victor y Enrique Dunwegge, "Ejemplos de la justicia", que decoran el hotel de la ciudad de Wessel.

Aun la música, la forma artistica más inefable, en la cual parece evanescerse la posibilidad de una constatación objetiva de carácter social. aún la música no ha escapado a influencia de tal orden.

Fl uso de poner en canto las leyes se empleó en Grecia, seqún anota Gognet en su "Origine des lois". Quien las anunciaba, to hacia con las reglas y las métricas de ina declamación, con açompanamiento de lira 
Recuerda Chassan en su "Essaí sur simbolique du droit", que en el Exodo se comprueba que la publicación de la ley entre los hebreos se hacia cantando.

Es obvio indicar que los himnos nacionales responden a un ideal patriótico. De otro lado, hay composiciones musicales que responden a una actitud polf́tica, La Sinfonía Heroica de Beethoven fue una entonación exultante a la libertad y de entusiasmo por la Revolución Francesa. Antes es de reparar en su obra titulada Ein grosses deatscbes Volk sind wir, y en la sonata al Emperador Alejandro. Romain Rolland ha escrito: "El carácter marcial, característico de esta música, recuerda la época en que fue escrita: la revolución llega a Viena y Beethoven era arrastrado por ella. Manifestaba en buena gana en la intimidad - nos dice el caballero Seyfried- su aprobación para los sucesos politicos, que juzgaba con una rara perspicacia, con mirada clara y penetrante". Del mismo Rolland sobre la Sinfonia Heroica: "Primera música verdaderamente revolucionaria; el espíritu de la época revive en ella con la intensidad y la pureza que tienen los grandes sucesos en las grandes almas solitarias, cuyas impresiones no son debilitadas por el contacto de la realidad". Las polonesas de Chopin se estremecen de rebeldía contra el sojuzgamiento politico. La Obertura Solemne de Tchaikowsky, llamada "Poema Sinfónico" por los críticos, fue compuesta para conmemorar el 50 aniversario de Rusia liberándose de la invasión napoleónica. Weinberger ha escrito su "Sinfonía a Lincoln" y recordará la Sinfonía de Schostakovicht, que me fue dable escuchar en el Carniege Hall de New York, en orquesta conducida por el insigne Kusevitsky, sinfonia que refleja el genio de la revolución soviética.

La ópera de Wagner "Las Walkirias", nos lleva a pensar en el valor de la justicia como una verité de raison, por decirlo así. Siegmund, hijo de Wotan, seduce a Sieglinde, mujer de Hunding, con quien ha de batirse. Wotan ordena a la Walkyria Brumnhilde ayude a Sicgmund; pero Fricha, esposa de Wotan y que representa la justicia, declara que aquél debe ser castigado: Wotan ha de obedecer e instruye a Brumnhilde de proteger a Hunding. quien pese a la desobediencia de la'misma, mata a su rival, gracias a la intervención de Wotan directamente. La justicia controla la voluntad de los dioses, impide que se dejen arrastrar por impulsos arbitrarios; la justicia ha de estar siempre al lado de esa voluntad, y de aquí que Fricka sea la esposa del dios del Walhalla; la justicia impera como un principio absoluto, axiologicamente supremo, por cima de toda otra razón de ser

Opera que merece ser rememorada es "Boris Guc unoff" de Moussor- 
gsky. Boris, Regente del Zar Fedor y culpable de la mucrte de Dimitri, a quien correspondía el trono, es estimulado por la nobleza para que ocupe el mismo. El monje Gregorio hace difundir la especie de que Dimitri no ha muerto y se hace pasar por tal, promoviendo una revolución. La Duma se reune para coronar a Boris; en esa oportunidad Chousky, un cómplice del Regente, revela lo acaecido con Dimitri; Boris se horroriza con el remordimiento y muere. mientras la rebelión de Gregorio fracasa, al saberse que era un simulador de la persona de Dimitri, y el hijo de Boris, Teodorus, asume el reinado. recibiendo el consejo de su padre moribundo, de gobernar con justicia. Aqui encontramos muchas enseñanzas notables. Boris debe expiar su delito. La revolución de Gregorio prospera al comienzo, cuando se juzgaba que la asistía una razón legítima: pero al descubrirse que tal no existe. el pueblo repudia una usurpación de poder. De otro lado, es de resaltar la escena del bosque de Konry, en el Tercer Acto, que muestra el resentimiento del campesinado contra la nobleza; indicio de la animadversión entre las clases sociales que siempre existió en la Rusia zarista.

Se ha propugnado en los últimos tiempos la producción de una mùsica que podria llamarse "militante". El compositor alemán Eisłer, el critico soviético Weiss y en Italia Marinetti, son del parecer que las obras musicales expresen la mistica política de los respectivos Estados totalitarios.

Fácil es percibir como el cinema exhibe con frecuencia asuntos que tienen que ver con abogados, clientes, jueces, delitos y sanciones, tribunales y jurados, matrimonios y divorcios, contratos, razones de Estado. temas que se conectan con la vida politica o que apuntan a fines de propaganda, adoptando, entonces, podria decirse, una actitud polémica. Asi será de mencionar "Camicie Nero". del Director Forzano, con tesis fascistas; "Submarinos rumbos al Oeste", de inspiración nacista; "Los marinos de Kronstadt", "La juventud de Maximo". "Chapayeff", afirmantes de la creencia soviética. Para el cineasta Eissenstein cl cine debe representar el heroismo, la fe. el ámima de ta revolución socialista, y en el Congreso de Volta reunido en Roma en 1934, se sostuvo que el arte debía ser orientado de acuerdo con directivas estaduales.

Algunos argumentos de las respectivas obras literarias, en que el leit motiv es juridico, son transportados al ecran con patética intensidad. Por ejemplo. "La Carta", inspirada en la obra de Sommerset Maughan con el delito de Leslie Crosbie, su juzgamiento, la intervención del abogado 
que conociendo que es responsable, no obstante solicita por deber profesional, sea absuelta; pero sin que pueda impedir que por fatta de sinceridad, evacúe su alegato sin efusión. "La Llama Secreta", del mismo autor, con la muerte causada a Mauricio Taulet por su madre dona Isabel, para ahorrarle sufrimientos incurables y para que pueda ser feliz su otro hijo, Carlos, quien ama a la esposa de Mauricio y es amado por ella; el problema de la eutanasia que surge, y la actitud de los circunstantes, que consideran que no debe denunciarse el hecho. "FI Prisionero de Zenda", de Antonio Hope, en que por una razón de Estado se substituye al Rey Rodolfo por Rassendyll, para que no se encarame en el gobierno el sombrio Duyue Miguel. "El Culpable" de Françoís Coppé, con la semblanza del Fiscal Lescuyer, su intervención en el proceso en que acusa a su hijo, y el dramático final en que Lescuyer se declara responsable por el abandono de aquël y explica las circunstancias que impulsaron a su hijo a cometer el crimen. "El juicio de Mary Dugan" de Bayard Vailler (rodada no hace mucho con el nombre de "Trágica Red"), en que todo gira alrededor de un juzgamiento criminal. "Resurrección" de Tolstoy, con el enjuiciamiento de Katuscha Maslowa y el pensar que si hubo culpa fue de la sociedad y no de la condenada. o indirectamente de Nekhundoff, quien la sedujo y la abandonó, con la ironía que él fuera uno de los miembros del Jurado. "La Cabaña del tio Tom" de Beecher Stowe, la obra literaria de protesta contra la esclavitud de los negros. "No estamos solos" de James Hilton. en cuanto se imputa un envenenamiento a dos personas inosentes, condenandoselas en virtud de determinadas presunciones; lo que conduce a reflexionar cómo a veces se sentencia sólo presuntivamente y como el jucz, no obstante, no puede hacer otra cosa. "Crimen y Castigo" de Dostoiweski, con Raskoinikoff, congénitamente bueno, que mata no por odio o interés, sino como instrumento del destino o reacción inconsciente de la colectividad frente a la usurera detestable, y con el desasosiego que su crimen le suscita y que le lleva a confesarlo, para encontrar la expiación en el castigo. "David Copperfield", de netos perfiles juridicos, como todas las novelas de Dickens. Los films en que se ha descrito la vida y obra de personajes políticos: Federico de Prusia, Victoria de Inglaterra, Lincoln, Juárez, Scipión el Africano, Cristina de Suecia. Catalina de Rusia, Napoleón, Enrique VIII de Inglaterra, Iván el Terrible, Dantón, Cecil Rhodes, entre varias.

Es pertinente traer a colación otras películas. Por ejemplo, la titulada "Más fuerte que el parágrafo", que presencié en un cinema de Berlin, en la cual se procesa a un individuo. contra quien se conjuran indicios adversos, habiéndose cometido el crimen por otra persona, que lo revela a su abogaúo: violando éste entonces el secreto profesional, por el impera- 
two de conciencia de salvar a un inocente. "Mr. Smith goes to Washington" (aparecida bajo el nombre de "Caballero sin espada"), mordaz crítica a ciertas practicas parlamentarias y el falso civismo del político encumbrado: pero con el triunfo, finalmente, de la fe del protagonista en los méritos de la democracia. "Vidas robadas", con la substitución de personalidad, usurpación de nombre y de estado civil que tienen lugar; punibles dentro de un legalismo ortodoxo, pero que conforme a las circunstancias en que ellas acaecen. en el desarrollo de la película, resultan disculpables. "Apolo me llaman", que nos presenta al abogado lleno de vivacidad y ardides, al servicio de gansters y especuladores, que, no obstante, para salvar el amor de dos jovenes en el fondo buenos, denuncia a su cliente, siendo usesinado por él mismo, mientras recita un pasaje del "Julio César". "La vida de Emilio Zola", con Paul Muni, con el proceso Dreyfus, el respectivo error judiciario y la resistencia para reonocerlo por causa de intereses creados y circunstancias inconfesables. El caso de "El Correo de Lyon". otro desacierto judicial y que demuestra la falibilidad de las declaraciones testimoniales. "Cargo de conciencia", con Raimu, que interviene en un proceso en que se cree que la encausada es culpable; pero la apreciación serena de dicho miembro del jurado le lleva a hacer las preguntas sagaces que revelarín la inocencia; sugestiva enseñanza de cómo no desembocándose en un precipitado veredicto. es evitable una fatal equivocación. Las películas sobre la familia Hardy, con el tipo del buen juez que encarna Lewis Stone, con su criterio ponderado, que basca las conciliaciones donde sean posibles y juzga mediante consideración directa de los hechos capitales; presentíndose de otro lado, en su vida de hogar. como buen padre y buen esposo. Chaplin ha desempeñado roles en que insurge generalmente una implicita censura contra la organizacion social que se llama capitalista.

Es visible el empalme de derecho y literatura, Se han hecho estudios especiales sobre el particular. Asi, Müller y Fehr respecto de la literatura alemana. Hinojosa acerca del Mio Cid, Ortolán con relación a La Divina Comedia, White referentemente a Shakespeare, Marschall en su libro "The lawyer in literature". Irwing Brown en "Law and Lawyer in the literature". Pons y Umbert sobre el ideal de justicia de Don Qujote, Solmy en "Il penseiro politico di Dante". Perticoni en "La filosofía de Stato nei tempi e nella mente di Dante Alighieri". Kohler en "Shakespeare vor dem Forum der jurisprudenx".

Fuera de lo anterior, "cuanto por tratar sobre otros autores que se 
han planteado problemas juridicos! Asi Dostoiewski en "Crimen y Castigo" y "Los hermanos Karamasoff"; Calderón de la Barca en "El Alcalde de Zamalea" y "La Vida es Sueño"; Lope de Vega en "Fuente Ovejuna". "El mejor alcalde el Rey", "La Estrella de Sevilla", Anatole France, caracteristicamente en "Crainquebille"; Kleist, sobre todo en el intenso "Micheael Kohlhaas"; Wassermann, de preferencia en "El caso Maurizius"; Racine, singularmente de "Los Plaideurs"; Borky, Zola, Hugo, calificables como escritores sociales; Schiller, Quevedo, Dickens, Walter Scott, que tambièn han aprovechado aspectos concernientes a nuestra materia.

"El Mercader de Venecia" es una obra cminentemente jurídica. La demanda de Shylock importa un ejercicio anormal del derecho. Dos postulados pugnan en el tesisimo dilema que estremece a la filosofia del derecho: seguridad versus justicia. Shylock defiente la primera, exigiendo la ejecución indefectible de lo convenido. Por eso afirma:

-Shylock: "Quiero que se cumplan las condiciones de mi pagaré; no quiero escucharte; por consiguiente, no me hables más ... Quiero el cumplimiento del pagaré". (Acto III. escena 3a.).

Pero la oposición se apoya en la mala fe, la inmoralidad, el animus nocendi, la desviación del contrato de su fin propio. Por eso se propugna:

-Basanio: "Os suplico por una sola vez que hagáis flaquear la ley ante vuestra autoridad; haced un pequeno mal para realizar un gran bien y doblegad la obstinación de este diablo cruel", (Acto IV; escena 1a.).

Otro caso de abuso de derecho se encuentra en Don Quijote de la Mancha (Capitulo IV. parte 1a.). De la espesura de un bosque salen voces delicadas y dolientes; atado a una encina está un muchacho, al que su amo azota. Instintivamente Don Quijote va al campesino, a detenerlo en su desmán. Juan Haldudo alega que su criado ha infringido sus deberes y por eso le castiga. Don Quijote en esta oportunidad, como de costumbre, se siente juzgador de jure propio. Y falla inmediatamente, sin mayores pruebas ni argumentaciones. Su sentido intuitivo de la justicia le advierte donde ésta reside. Quizás sea cierto lo que manifiesta el rico de Quintanar; pero obra de una manera calificable como de un uso anormal del derecho. Con la relación de amo y criado. patrón y dependiente, conductor y locador de servicio, es incompatible el proceder empleado, que atenta contra la consideración propia para todo ser huma 1 . Esa relación no 
autoriza para humillar, agredir, ofender, torturar of wgunde al primero La comunidad en cierto modo de vida y babor entre el que presta el servicio y el que lo obtiene, debe. por el contrario. erear un espiritu de solidaridad. El mismo Don Qujote sugiere este punto de vista, cuando al encontrarse con los cabreros (Capitulo XI. la. parte), dice a Sancho: "Quicro que aqui a mi lado y en compañia de esta buena gente te sientes. y que seas una misma cosa conmigo, que soy tu amo y senor natural. que comas en el plato y bebas por donde yo bebiera ${ }^{*}$. Fn el capitulo 11 de la Segunda Parte, aparece diciéndole: "Quiero decir que cuando la cabeza ducle. todos los miembros duelen, y asi. siendo yo tu amo y semor. soy tu cabeza y tú mi parte. pues eres mi eriado: y por esta razón el mal que a mi toca o tocare, a ti ha de doler, y a mi el tuyo". Aqui hay, por ot ra parte. un trasunto de lo que pueda entender por daño moral.

Fn el pasaje antes analizado, de tal aventura con Andrés y ef de Quintanar. es conveniente percibir cómo don Quijote. quien atetua de juzgador, afirma categoricanente el acatamiento que por ello se merece. "Basta que yo se lo mande para que me tenga respeto". Y por eso imoca la coacción fucra de necesidad, cuando amenaza: "Si no, por el mismo juramento juro de volver a buscaros y castigaros aqui".

El susodicho pasaje esta lleno de interés para todo jurista. Quizas un veredicto como el pronunciado es peligroso, por la precipitacion. por el apasionamiento que actisa. Pero es que aquí se trasluce una mancra de proceder libre de los inconvenientes de común empleable por el juez. profesional, con su demora caracteristica, sus hesitaciones y timideces. derivadas de un exceso de logicismo, de alambicados analisis de casuistica. con su cansancio soholiento y su desdén un tanto desabrido, que le apartan de contacto directo, intimo con la matcria cuestionada y dificultan que logre asit y apasionarse por la justicia mediante una intuición inmediata, una endopatia. uns proyección sentimentat que instantáneamente lo proyecta a ella.

Por eso se comprende la decisión del noble Manchego, libertando a los galeotes (Capítulo XXIII. La. parte), la cual ante un criterio rigurosamente legal es insostenible. (Véase las recriminaciones del cura Pero Pèrez en el capítulo XXIX. 1a. parte). Pero la actitud de Don Quijote es explicable desde su punto de vista, cuando dijese: "Fn resolución, como quiera que ello sea. esta gente aunque los llevan, van de por fuerza y no de su voluntad"; agregando: "Porque me parece duro caso hacer esclavos a los que Dios y la naturaleza hizo libres". En esta ocasión también. to que el toma en cuenta es el hecho en sí en su más diáfana sinceridad. Lo demás. 
los motivos circunstanciales del apresamiento, es intrascendente para su idiosincrasia idealista.

Otro capitulo, entre muchos, de la imperecedera obra de Cervantes que es digno de destacar para nuestro propósito, es aquèl en que resplandecen los sabios consejos a Sancho, al ir éste a gobernar la Insula (cap. XLII, 2a. parte). En èl se lee: "Cuando pudiere y debiere tener lugar la equidad, no cargues todo el rigor de la ley al delincuente; que no es mejor la fama del juez riguroso que la del compasivo". En otra parte se advierte (cap. XXXII, 2a. parte) que to fundamental en los gobernantes está en que tengan buena intención y deseen acertar en todo. Tbe King can do not wrong. Así lo ensena Shakespeare en "Julio César":

-César: "Sabe que César no es injusto; no sin causa se dará por satisfecho" (Acto III, escena la.).

El gobernante debe procurar que prevalezca la justicia, amparando a quien la tiene y abatiendo a quien la infrinja. Recordemos "El mejor Alcalde el Rey" de Lope de Vega:

-Rey: "Ofendido de rigor, de la violencia y porfia de don Tello, yo en persona le tengo de castigar", (Acto II, esc. 2a.).

-Sancho; "Señor, mirad que no os toca tanto mi bajeza honrar:

enviad que es justa ley para que se haga justicia, algún alcalde a Galicia".

-Rey: "El mejor alcalde el Rey", (id).

Puede ocurrir a veces que sea muy difícil optar entre una u otra solución: un legalismo riguroso o una benévola dispensa. Entonces el gobernante y el juez deben recordar el consejo de Don Quijote antes transcrito. Esto atane sobre todo al gobernante. La función pública infunde dignidad y por lo mismo magnanimidad. Es lo que se desprende de "Hernani" de Víctor Hugo. Al Rey don Carlos y a Hernani una cuestión personal les distancia. Mientras el primero visita la tumba de Carlomagno, penetran los conjurados, dirigidos por don Ruy y Hernani, con el propósito de asesinar al Rey. Retumba entonces el cañón, tres veces: la señal que iadica que don Carlos ha sido designado Emperador El mismo 
sale de la rumba a ticmpo que los conspiradores son aprehendidos. Perdona a Hernani y auspicia que se case con doña Sol. a quien don Carlos codiciaba. La investidura imperial to ha aportado la consiguicnte generosidad. "Siñores dice,- ignoro vucstros nombres: quiero olvidar en lo ahsoluto mi colera y odio. Itlos yo os perdodo. Is la lección que conviene que dé al mundo" tacto IV, esc. 4a.) Agrega. en el sublime monólogo con que concluye el acto: "Y te insoguc diciendote: por dónde debo cmpezar? Y tu me has respondido: „Hijo mio, por la clemencia!".

En la obra de Calderon de la Barca "La Vida es Sueno", encontramos una afirmacion de indole juridica:

\section{S'gismundo: "Fn que no ex justa ley \\ no ha de obedecer al rey. \\ y su principe cra yo", (iornada 2a., exc. 3a.).}

Aquí se nos presenta la aporia de hasta qué punto debe acatarse la k'y. asi sca injusta. Ia ley se produce para realizar la justicia. Esta puede comsiderarse cono la causi final y formal. como la cntelequia de la ley, y no obstante. la adecusción wo es siempre perfecta: aun más, es posible que entren en contlicto Cuil dehe predominar y cual debe ser sacrificada? Consegur to justo per se con desire de lo estrictamente legal, parece ser fo que en primer térmuno gane la consideración. Por la justicia clamamos. sobre todas las cosas y por evo si se frustra en la tierra. se invoca la divina. Fn "Whalhelm Telf" de Schiller s lee. "Cuando el oprimido en parte alguna puede hallar la fusticia y se le hace insoportable tal agravio, extiende las manos con confrado valor. al ctelo y busca la justicia eterna que alli mora, inmutable e inviolable como las mismas estrellas"*, Acto II, escena 2.t.

Fn wale punto es procedente tratar de la obra de Sófocles, "Antigona". Justicia intrinseca y legalidad rigurosa $s$ oponen netamente, segun lo pone de manifiests, entre otros. Stammler en su "Practikum der Rechtphilowohic". Antigona exclama: "Porque ni Zeus ha hecho tales leyes, ni la justicia que yace con las deidades subterrineas. $\mathrm{Y}$ no he ereido que tus adictos podian rebelarse contra las leyes no escritas e inmutables de los dioses, ya que tú no eres sino un mortal. No de hoy ni de ayer que ellas son inconmovihles, sino que son eternamente validas y nadie sabe descle que momento han nacido". (Acto 2a. esc. 2a.). Asimismo increpa: " Cuâl es la justicia que he violado?... Si los dioses aprobaren esto. reconoceria la legitimidad de mi castigo: mas. st los hombres son inicuos. yo no quiero que sufran mayores males de los que me inflingen indebida- 
mente". (Acto III, esc. 5a.) Hemon, por su lado, advierte a su padre: "No escuches nada que sea injusto" (acto III. esc. Iia.). "Te veo errar en agravio de la justicia" (id.) Pero Ismena previene a su hermana que debe obedecer los mandatos de la autoridad. El Coro dice al Rey: "Estamos sometidos a tu ley, cualquiera que ella sea" (Acto I, ese, 3a.). "Es acto piadoso honrar a los muertos; pero no está permitido en lo absoluto desobedecer a quien tiene autoridad (Acto III, esc. 3a.). Creon conmina: "Aquél que ha violado las leyes y que obra erróneamente contra su jefe, no será loado por mi. Es preciso obedecer a quien la ciudad ha reconocido por su gobernante, en las cosas grandes o pequeñas, justas o injustas". (Acto III, esc. la.).

Retornando al "Whilhelm Tell" de Schiller, es de reparar en la tesis que proclama en favor de la independencia politica nacional. Los campesinos suizos rebélanse contra la dominación extranjera, aceptada anteriormente, pero que es ejercida por Gessler con desconocimiento de los derechos naturales humanos: y Reding dignifica la insubordinación cuando promete: "Juro por las estrellas inmortales, que no me apartaré de la justicia". (Acto II, esc, 2a.). "Posecmos este suelo por miles de años, iy el mandatario de un soberano extranjero puede pretender venir a forjarnos cadenas y cubrirnos de ignominia en nuestra propia tierra? -exclama Stanfacher (Id.). El comicio popular acuerda desconocer la odiosa autoridad de Gessler. "Ahora sois libres gracias a esta ley", proclama Rooselmann (Id.) Walther Fürst dice: "Queremos sustracrnos a esta abominable dominación; queremos conservar nuestros antiguos derechos, como los heredamos de nuestros padres ... queremos ser libres como lo fueron nuestros antepasados; primero la muerte que vivir en la esclavitud. Queremos confiar en Dios omnipotente y no temer al abuso de los hombres" (Id.).

En la misma obra se plantea el crimen político. El Emperador Alberto es asesinado por el Duque Juan de Suabia. Fürst censura el hecho; "crimen inútil: la venganza no da nunca frutos". (Acto V.; esc. la.). Tell increpa al delincuente: "¡Asesinar a vuestro tio, a vuestro Emperador! ¿Y aún la tierra os tolera? :Aủn el sol os alumbra? ... ¿Y manchado con la sangre del asesinato de tu padre y emperador, osas entrar en mi honesta casa? ¿ ${ }_{i} \mathrm{Te}$ atreves a mostrar tu rostro a un hombre honrado, solicitando hospitalidad? .. Levanto al cielo mis manos limpias. Abomino de tí y de tu crimen. Yo tomé venganza en nombre de los sagrados derechos de la naturaleza: tĩ fos has profanado. Nada hay de común entre nosotros: tú has asesinado, yo he defendido to que más caro me era" (Acto IV.. esc, 2a.). 
También al delito por causa politica se alude en "Julio César" de Shakespeare. Bruto expresa su admiración y amor por César; pero subraya que actúa por "motivo de necesidad y no por odio" (Acto II, esc. 1a.): a diferencia de Casio. La propia cohonestación del crimen por Bruto es, no obstante objetable. Por eso Antonio lo presenta ante la censura popular, aunque hipócritamente habla de los propósitos plausibles que le impulsaron al homicidio. "Os muestro las heridas del bondadoso César, pobres bocas mudas, y les pido que hablen por mi!". (Acto II, esc. 3a.). Por lo demás. Plutarco nos relata la acusación kegalmente fundada, que ordenara Octavio contra Bruto y Casio. También se recordará que Dante ubica a los mismos en uno de los circulos del Infierno:

"Degli altri due, ch'hanno'l capo si soto, Quei che pende del nero ceffo, ì Brutto: Vedi, como si storce, e non fa motto: F. l'altro è Cassio, che par si membruto". (canto XXXIV: 64-67).

Son muchas las indicaciones que podrian hacerse sobre problemas jurídicos destacados en obras de arte en general y de literatura especialmente, ¡Cuántas sugerencias se ofrecen al respecto a la imaginación polifurcante! El derecho no se contiene sólo dentro del sector especifico de lo que se califica propiamente como tal. A semejanza de la sangre que circula en todo el organismo, aquél se expande por todas las manifestaciones de la vida humana. El derecho no opera únicamente en la solemne y austera prestancia de los Pretorios, en las fórmulas lacónicas de los preceptos de la ley, en la mecáncia de la praxis procesal, en las exposiciones lógicas de los letrados, en la exegética de los comentarios de los jurisprudentes. Irrumpe a otras regiones, en que funcionan otros datos, como ocurre respecto al Arte, para que los temas juridicos sean acogidos. deliberada y subconcientemente, y tratados por el artista. El derecho, el fenómeno al parecer más lógico, se evade en una admirable liberación, de sus límites circunstanciales, y penetra e inspira aquel mundo de maravilla que es el Arte.

$\mathrm{Si}$ estudiamos el derecho con esta visión generosa y descubrimos su influencia en otras esferas, como en la artístiea excelentemente, la misión del jurisconsulto adquiere una importancia insospechada. Asi. es inconcuso, se logra una comprensión más rica, humanamente más amplia, de lo que es el derecho y su significado. La jurisprudencia coloniza nuevos campos de investigación y gana ingentemente en grandor $y$ hondura, en 


\section{NUESTROS CLASICOS}

elegancia y dignidad. Aprendemos de tal stierte a conocer mejor lo que es la justicia, las leyes y su debida interpretación, pues no en balde la sabiduria de El Quijote intuyó que el fin de las letras humanas es "poner en su punto la justicia distributiva, y dar a cada uno lo que es suyo, entender y hacer que las buenas leyes se guarden". (Cap. XXXVII: 1a. parte). 